International Journal of Physical Sciences and Engineering
Available online at www.sciencescholar.us
Vol. 6 No. 1, April 2022, pages: $9-17$
e-ISSN : 2550-6943, p-ISSN : $2550-6951$
https://doi.org/10.53730/ijpse.v6n1.3065

\title{
Design of Air Temperature and Humidity Measurement Based on Arduino ATmega 328P with DHT22 Sensor
}

\begin{tabular}{|c|c|}
\hline \multicolumn{2}{|c|}{ () CrossMark } \\
\hline \multicolumn{2}{|c|}{ Manuscript submitted: 27 November2021, Manuscript revised: 18 December2021, Accepted for publication: 09 January2022 } \\
\hline Corresponding Author a & Abstract \\
\hline & $\begin{array}{l}\text { The Arduino ATmega 328P-based temperature and humidity measuring } \\
\text { instrument have been successfully designed. The ATmega 328P microcontroller } \\
\text { functions to process data which is the output of the DHT22 sensor which } \\
\text { receives data signals in the form of temperature and humidity. The results } \\
\text { detected by the design of this tool are displayed on the LCD keypad shield. The } \\
\text { calibration process for the design tool was carried out at the BMKG Sanglah } \\
\text { Denpasar. The results of the calibration of the design tool with reference tools } \\
\text { at BMKG show a good level of accuracy, namely } 97.97 \% \text { for air temperature and } \\
99.35 \% \text { for air humidity. }\end{array}$ \\
\hline
\end{tabular}

Keywords

Arduino;

ATmega 328P;

DHT22 sensor;

humidity;

LCD keypad shield;

International Journal of Physical Sciences and Engineering (C) 2022.

This is an open access article under the CC BY-NC-ND license (https://creativecommons.org/licenses/by-nc-nd/4.0/).

\section{Contents}

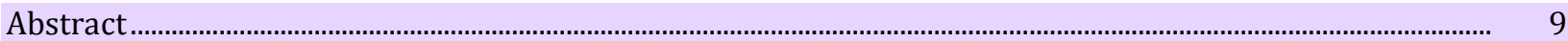

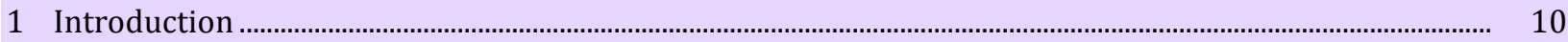

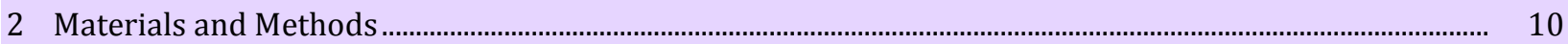

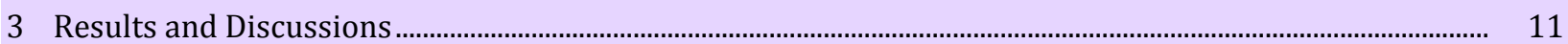

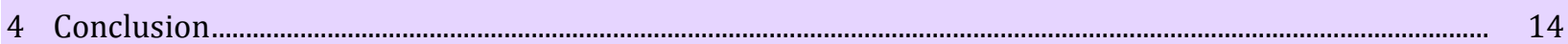

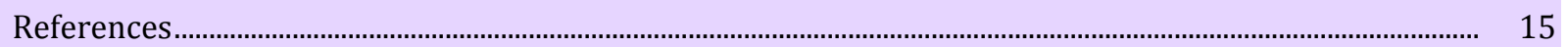

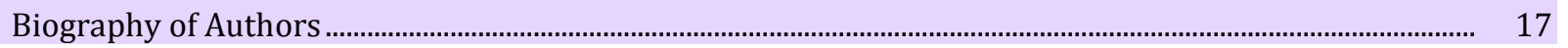

a FMIPA, Physics Study Program, Universitas Udayana, Denpasar, Indonesia

b FMIPA, Physics Study Program, Universitas Udayana, Denpasar, Indonesia 


\section{Introduction}

Air temperature and humidity have a very important role in various aspects of living things, especially nowadays temperature and humidity are very decisive factors in various business fields, especially in the industrial sector, both large and small scale (home industry). The existence of a tool that functions to control temperature and humidity is one of the determining factors to obtain maximum results as expected. In the large-scale industrial sector, for example in the agricultural and livestock industries, the function of measuring air temperature and humidity is an indispensable tool for monitoring the quality of a plant, some plants are strongly influenced by the temperature and humidity of the air. Sumartini (2017), in the livestock sector, temperature and humidity measuring instruments are needed to control the cage (chicken), so that the productivity and quality of livestock increase (Ferdoush \& Li, 2014; Gehlot \& Jain, 2020).

Meanwhile, in the health sector, temperature and humidity are very influential in several activities of a room such as inpatient rooms, operating rooms and intensive care, storage of medical equipment, storage of photographic devices, and others (Sumartini, 2017). In addition, government institutions such as the BMKG also require temperature and humidity measuring devices in determining weather forecasts, early warnings, and others (BMKG, 2019). The very lack of domestic production in the field of developing instrumentation tools for measuring temperature and humidity, resulted in the prices of these tools being relatively expensive because they had to be imported from outside. The size of the tool which is quite large is also an obstacle so that the level of mobility will be hampered. The tool that will be designed is based on Arduino ATmega 328P as the main processor and DHT22 sensor, and the tool that will be designed besides being smaller in size is also able to provide information on the quality of temperature and humidity in real-time in one device. The results of the detection will be displayed on the LCD so that it can provide direct information about the temperature and humidity of the air to observers and the public (Sharma et al., 2021; Wang et al., 2021).

\section{Materials and Methods}

In general, the block diagram for designing a tool to measure air temperature and humidity based on Arduino ATmega 328P using a DHT22 sensor (Pereira et al., 2020; Tai et al., 2020). The flow diagram in Figure 1 starts with the DHT22 sensor which converts the input signal in the form of temperature and humidity into an analog signal in the form of voltage. The Atmega328P microcontroller that has been installed on the Arduino already contains an analog to digital converter (ADC) which will convert analog signals into digital data. The digital data that is read will then be processed by the Arduino Uno microcontroller and will then be forwarded to the laptop (Aprianah, 2013; Arnold \& Griffin, 2007). Programming is done using the Arduino IDE software so that the ias tool works as desired. After the program code is finished, it is then input into the microcontroller and the output is generated via the LCD keypad shield, and ias is also directly displayed through the Arduino software on the serial monitor. The design scheme of the tool is shown in Figure 1.

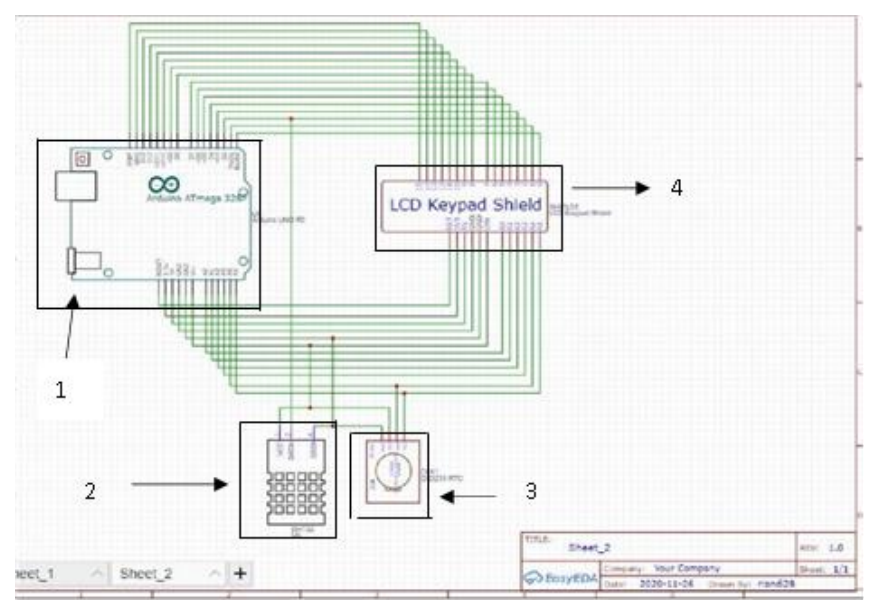

Figure 1. Schematic of the design of air temperature and humidity measuring instruments 


\section{Results and Discussions}

This research begins with designing a temperature and humidity measuring instrument based on Arduino ATmega 328P with a DHT22 sensor (Nasional, 1990; Dhofir, 2014). This design broadly consists of hardware in the form of a design tool that functions as a measuring tool. The drawing of the measuring instrument design can be seen in Figure 2 .

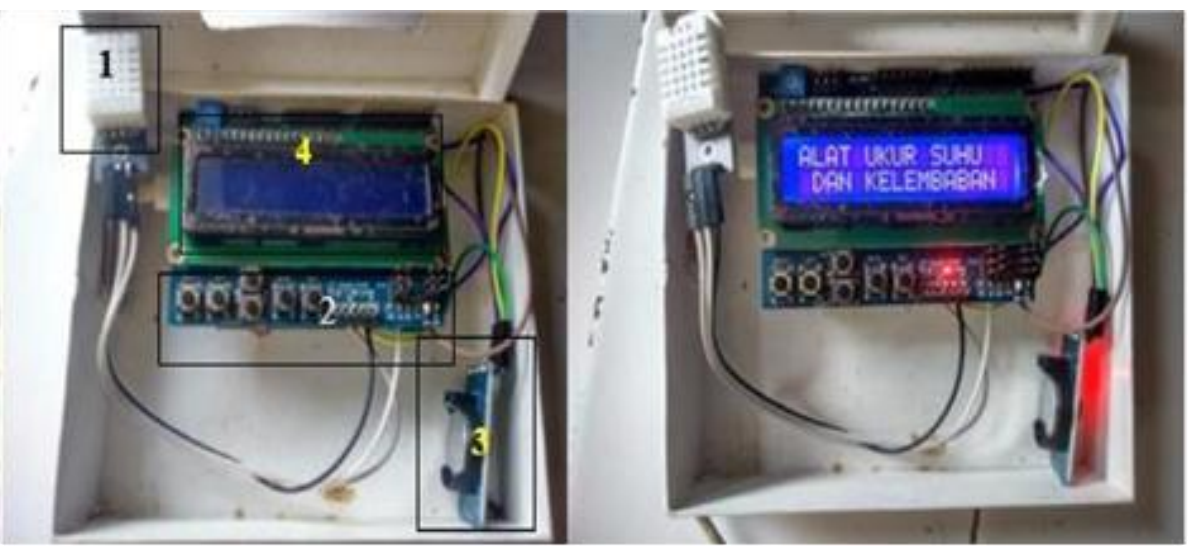

Figure 2. Design of digital air temperature and humidity measuring instruments

Figure 2 shows an overall picture of the design of the temperature and humidity measuring instrument. Based on Figure 2, the design of the air temperature and humidity measuring instrument consists of the following parts:

1) The DHT22 sensor module functions to measure air temperature and humidity. The DHT22 sensor module has a humidity sensing component and a thermistor temperature sensing component.

2) Arduino Atmega 328P is the central system of all hardware systems. Arduino Atmega 328P performs several functions such as receiving signals from sensor readings, processing sensor reading data and converting them into temperature and humidity data and sending the data to the LCD.

3) The DS3231 RTC module functions to display the time (hour, date, and year).

4) LCD keypad shield functions as an output to display temperature and humidity data in digital form.

The software or program used in the design of this air temperature and humidity measuring instrument is the Arduino IDE (Integrated Development Environment) which is the default software from Arduino itself, where the Arduino IDE is the main controller of the DHT22 sensor measurement results using the C language. Embedded in the Atmega 328P microcontroller using a USB to serial converter (Giler \& Cedeño, 2020; Vallejo et al., 2019). This program runs the processing of the output from the sensor, DS3231 and LCD keypad shield based on the command received. Calibration, Data Analysis and Discussion. The design calibration of the Arduino Atmega 328P-based temperature and humidity measuring instrument was carried out at the BMKG office, Sanglah Region III Geophysics Station, Denpasar (Green \& Dyer, 2009; Rittersma, 2002).

Table 1

Calibration results of design tools with reference tools

\begin{tabular}{ccccc}
\hline \multirow{2}{*}{ Timing } & \multicolumn{2}{c}{ Air temperature $\left({ }^{0} \mathrm{C}\right)$} & \multicolumn{2}{c}{ Humidity (\%) } \\
& Design tool & Reference tool & Design tool & Reference tool \\
\hline 07.00 & 26,5 & 26,7 & 84,8 & 83,1 \\
08.00 & 26,3 & 26,4 & 81,9 & 80,3 \\
09.00 & 27,2 & 27,3 & 74,1 & 73,5 \\
10.00 & 28,5 & 28,6 & 63,8 & 62,4 \\
\hline
\end{tabular}

Wibawa, I. M. S., \& Putra, I. K. (2022). Design of air temperature and humidity measurement based on Arduino ATmega 328P with DHT22 sensor. International Journal of Physical Sciences and Engineering, 6(1), 9-17. https://doi.org/10.53730/ijpse.v6n1.3065 


\begin{tabular}{|c|c|c|c|c|}
\hline 11.00 & 29,7 & 29,5 & 56,8 & 55,2 \\
\hline 12.00 & 30,3 & 30,2 & 53,9 & 52,1 \\
\hline 13.00 & 31,1 & 31,3 & 58,8 & 56,2 \\
\hline 14.00 & 31,3 & 31,1 & 57,1 & 57,4 \\
\hline 15.00 & 30,1 & 30,2 & 57,2 & 55,6 \\
\hline 16.00 & 30,2 & 30,1 & 59,2 & 58,8 \\
\hline 17.00 & 28,4 & 28,3 & 61,1 & 60,6 \\
\hline 18.00 & 26,7 & 26,4 & 66,8 & 65,3 \\
\hline 19.00 & 26,4 & 26,5 & 66,5 & 66,1 \\
\hline
\end{tabular}

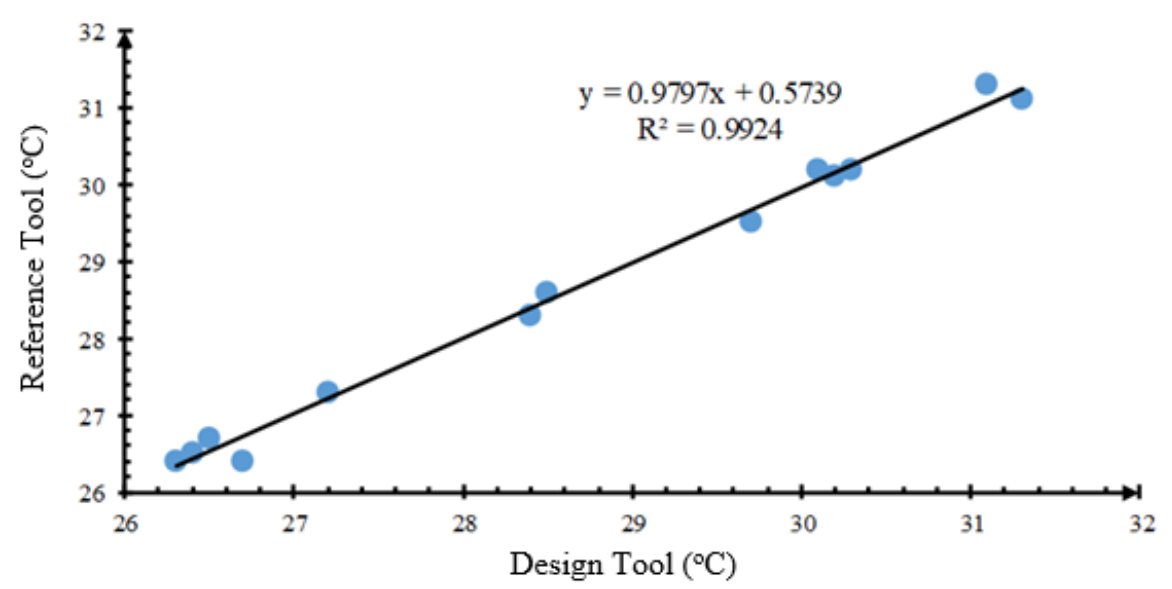

Figure 3. Calibration graph between the temperature of the design tool and the reference tool

Figure 3 shows a calibration graph between the air temperature measuring instrument from the design and the temperature measuring instrument at the BMKG Sanglah Station as a reference (Djuandi, 2011; Giancoli, 2001). The data used is the reading data at the time of tool calibration according to Table 1 . Figure 4 shows linear results between the design tool and the reference between the $\mathrm{x}$ and $\mathrm{y}$ axes. The coefficient of determination ( $\mathrm{r} 2$ ) from the graph has a fairly high value, which is 0.9924 . The coefficient value states that the suitability of the measurement by the design of the tool with the reference tool in the BMKG Sanglah Station is used as a comparison of 99.24\% (Marian \& Marian, 2016; Riyanto, 2017; Saptadi, 2014). The error in measurement occurs at the time of data collection not at the same time or from sensor sensitivity that is less.

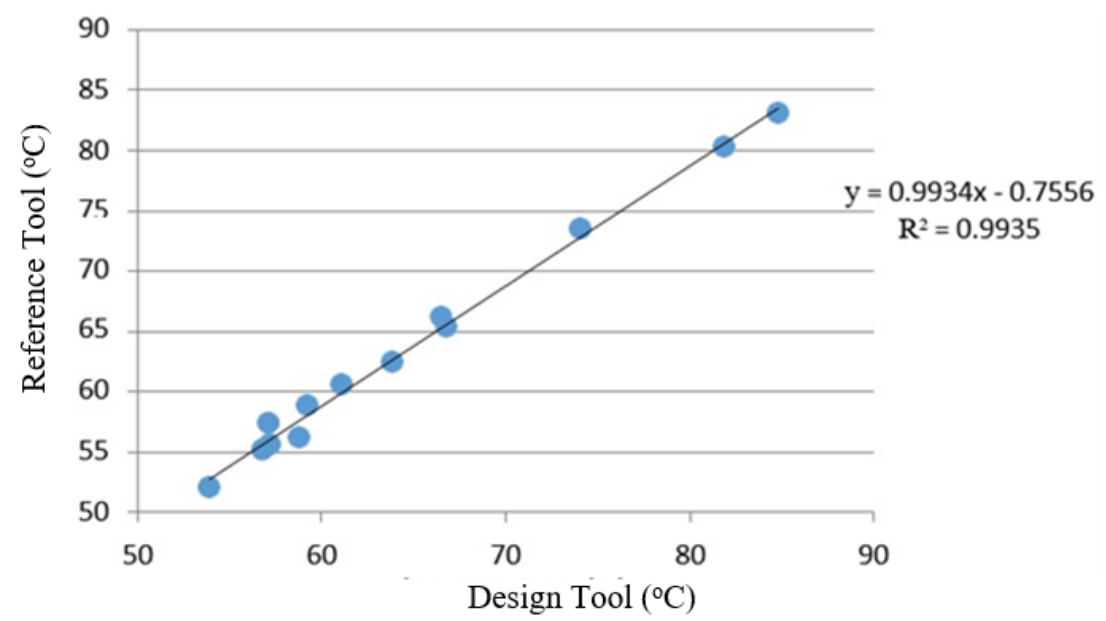

Figure 4. Calibration graph between the humidity of the design tool and the reference tool 
Figure 4 shows a calibration graph between the air humidity gauge from the design and the air humidity gauge at the BMKG Sanglah Station as a reference (Handoko, 2008; Heryanto \& Wisnu, 2008). The data used is the reading data at the time of tool calibration according to Table 1. Figure 5 shows a linear result between the readings of the design tool and the reference tool, namely between the $\mathrm{x}$ and $\mathrm{y}$ axes. The coefficient of determination (r2) from the graph has a fairly high value, which is 0.9935 (Munir \& Anselmi-Tamburini, 1989; de Souza et al., 1997). The coefficient value states that the suitability of the measurement by the tool design with the reference tool at the BMKG Sanglah Station is used as a comparison of 99.35\%. Errors in measurement, especially in reading data in the field, are one of the most common errors, besides that the sensitivity of the sensor also causes the accuracy of reading data in the field to be a very decisive factor in research.

Table 2

Results of application of design tools in Jimbaran

\begin{tabular}{ccc}
\hline Timing & Air temperature $\left({ }^{0} \mathrm{C}\right)$ & Humidity $(\%)$ \\
\hline 07.00 & 26,2 & 94,2 \\
07.30 & 27,2 & 92,1 \\
08.00 & 27,7 & 91,1 \\
08.30 & 28,2 & 90,5 \\
09.00 & 28,4 & 89,3 \\
09.30 & 28,9 & 84,6 \\
10.00 & 29,6 & 81,2 \\
10.30 & 30,4 & 79,7 \\
11.00 & 30,5 & 79,3 \\
11.30 & 30,7 & 77,3 \\
12.00 & 31,5 & 75,7 \\
12.30 & 31,7 & 75,0 \\
13.00 & 31,7 & 74,7 \\
13.30 & 31,9 & 74,2 \\
14.00 & 32,2 & 73,9 \\
14.30 & 33,1 & 70,6 \\
15.00 & 32,4 & 73,7 \\
15.30 & 30,5 & 80,7 \\
16.00 & 30,4 & 82,2 \\
16.30 & 29,6 & 83,6 \\
17.00 & 29,0 & 86,2 \\
17.30 & 28,4 & 88,4 \\
18.00 & 28,1 & 90,3 \\
18.30 & 28,0 & 91,2 \\
19.00 & 27,9 & 91,3 \\
\hline
\end{tabular}

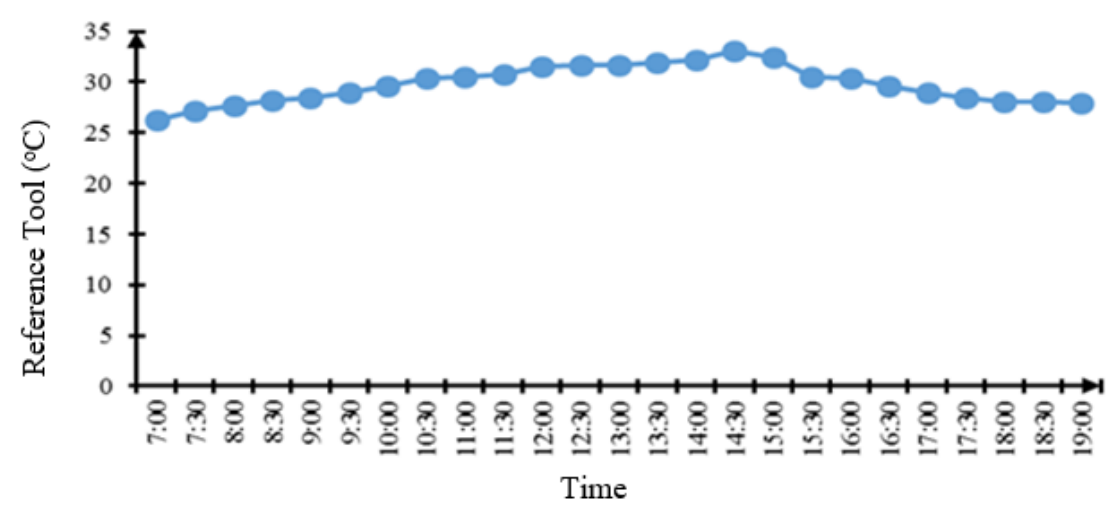

Figure 5. Graph of correlation between temperature and time

Wibawa, I. M. S., \& Putra, I. K. (2022). Design of air temperature and humidity measurement based on Arduino ATmega 328P with DHT22 sensor. International Journal of Physical Sciences and Engineering, 6(1), 9-17. 
Figure 5 shows that the correlation of the temperature of the design tool with the reference tool is very good, this can be shown from the overlapping of the points from the measurement results in the field (Utama, 2016; Abdulrazzak et al., 2018). At the time of calibration of the tool, the lowest temperature that was read on the design tool occurred at 07.00 i.e. the temperature was $26.20 \mathrm{C}$, while the highest temperature that was read on the design tool at 14.30 was 33.1 0C. Figure 7 shows the opposite, namely the highest humidity occurs in the morning at 07.00 at $94.2 \%$ and the lowest humidity occurs in the afternoon before the afternoon at $70.6 \%$ at 14.30 .

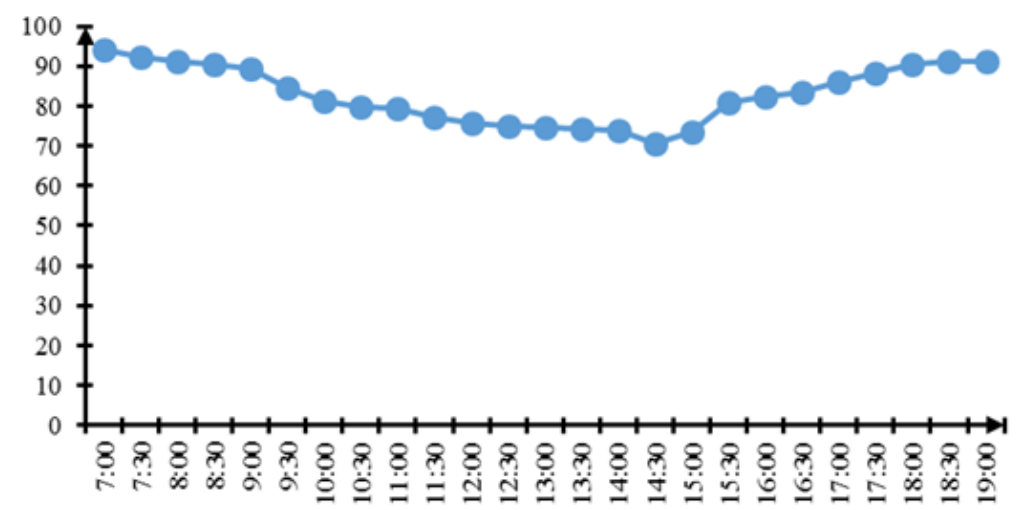

Figure 7. Graph of correlation between air humidity and time

\section{Conclusion}

The conclusions obtained from this research are as follows:

1) A temperature and humidity measuring instrument based on Arduino ATmega 328P has been successfully designed with a DHT22 sensor.

2) The working process of the design of the air temperature and humidity measuring instrument is the Arduino ATmega 328P as the main processor and the DHT22 sensor receives the data signal, the output is displayed on the LCD keypad shield.

3) The level of accuracy of the design compared to the reference tool is $97.97 \%$ for measuring air temperature and $99.35 \%$ for measuring air humidity. 


\section{References}

Abdulrazzak, I. A., Bierk, H., \& Aday, L. A. (2018). Humidity and temperature monitoring. Int. J. Eng. Technol, 7(4), 5174-5177.

Aprianah, D. (2013). Program Kendali Intensitas Cahaya Lampu Dan Pintu Via Message Service. Laporan Akhir Politeknik Negeri Sriwijaya.Juusan Teknik Elektro. Program Studi Teknik Telekomunikasi. Palembang.

Arnold, J. E., \& Griffin, Z. M. (2007). The effect of additional characters on choice of referring expression: Everyone counts. Journal of memory and language, 56(4), 521-536.

BMKG. (2019). Cuaca dan Iklim - Pengertian,Unsur Pembentuk dan Alat Ukurnya.

de Souza, S., Visco, S. J., \& De Jonghe, L. C. (1997). Thin-film solid oxide fuel cell with high performance at lowtemperature. Solid State Ionics, 98(1-2), 57-61. https://doi.org/10.1016/S0167-2738(96)00525-5

Dhofir, A. (2014). Pengukuran Suhu Termometer, Universitas Muhammadiyah Malang, Jawa Timur.

Djuandi, F. (2011). Pengenalan arduino. E-book. www. tobuku, 24.

Ferdoush, S., \& Li, X. (2014). Wireless sensor network system design using Raspberry Pi and Arduino for environmental monitoring applications. Procedia Computer Science, 34, 103-110. https://doi.org/10.1016/j.procs.2014.07.059

Gehlot, K. S., \& Jain, D. (2020). Biometric finger print based voting machine using ATmega328P microcontroller. Materials Today: Proceedings. https://doi.org/10.1016/j.matpr.2020.11.087

Giancoli, D. C. (2001). Fisika edisi kelima jilid 1. Jakarta: Erlangga.

Giler, J. J. G., \& Cedeño, C. N. P. (2020). Elaboration of bovine manure biodigester for biogas transformation to electric power. International Research Journal of Management, IT and Social Sciences, 7(5), 32-37. https://doi.org/10.21744/irjmis.v7n5.967

Green, J., \& Dyer, I. (2009). Measurement of humidity. Anaesthesia \& Intensive Care Medicine, 10(1), 45-47. https://doi.org/10.1016/j.mpaic.2008.11.016

Handoko. (2008). Pengamatan Unsur - Unsur Cuaca di Stasiun Klimatologi Pertanian. Jurusan Geofisika dan Meteorologi FMIPA-IPB. Bogor.

Heryanto, A., \& Wisnu, A. (2008). Pemrograman bahasa C untuk mikrokontroler ATMega8535. Yogyakarta: Andi Offset.

Marian, P., \& Marian, T. A. (2016). Quantum Fisher information on two manifolds of two-mode Gaussian states. Physical Review A, 93(5), 052330.

Munir, Z. A., \& Anselmi-Tamburini, U. (1989). Self-propagating exothermic reactions: the synthesis of hightemperature materials by combustion. Materials Science Reports, 3(7-8), 277-365. https://doi.org/10.1016/0920-2307(89)90001-7

Nasional, D. S. (1990). SNI 04-2051-1990. Baterai Kering.

Pereira, W. F., da Silva Fonseca, L., Putti, F. F., Góes, B. C., \& de Paula Naves, L. (2020). Environmental monitoring in a poultry farm using an instrument developed with the internet of things concept. Computers and Electronics in Agriculture, 170, 105257. https://doi.org/10.1016/j.compag.2020.105257

Rittersma, Z. M. (2002). Recent achievements in miniaturised humidity sensors-a review of transduction techniques. Sensors and Actuators A: Physical,96(2-3), 196-210. https://doi.org/10.1016/S09244247(01)00788-9

Riyanto, S. R. (2017). Rancang Bangun Alat Kontrol Suhu Dan Kelembaban Pada Fermentasi Tempe Kedelai Berbasis Mikrokontroler (Doctoral dissertation, Politeknik Negeri Sriwijaya).

Saptadi, A. H. (2014). Perbandingan Akurasi Pengukuran Suhu dan Kelembaban Antara Sensor DHT11 dan DHT22. Jurnal Infotel, 6(2), 49-56.

Sharma, D., Jain, R., Sharma, R., Shan, B. P., \& Shiney, O. J. (2021). Machine learning based BPM/Pulse interval predictor of human being using ATMega328p based development board. Materials Today: Proceedings. https://doi.org/10.1016/j.matpr.2021.07.411

Sumartini, T. S. (2017). Meningkatan Kemampuan Komunikasi Matematis Siswa Melalui Model Pembelajaran Predict Observe Explanation. Jurnal Edukasi dan Sains Matematika (JES-MAT), 3(2), 167-176.

Tai, H., Wang, S., Duan, Z., \& Jiang, Y. (2020). Evolution of breath analysis based on humidity and gas sensors: Potential and challenges. Sensors and Actuators B: Chemical, 318, 128104. https://doi.org/10.1016/j.snb.2020.128104

Utama, Y. A. K. (2016). Perbandingan Kualitas Antar Sensor Suhu dengan Menggunakan Arduino Pro Mini. $e$ NARODROID: Jurnal Berkala Program Studi Sistem Komputer, 2(2), 145-150.

Wibawa, I. M. S., \& Putra, I. K. (2022). Design of air temperature and humidity measurement based on Arduino ATmega 328P with DHT22 sensor. International Journal of Physical Sciences and Engineering, 6(1), 9-17. https://doi.org/10.53730/ijpse.v6n1.3065 
Vallejo, R. S. R., Gámez, M. R., Espinales, A. M. S., \& Pérez, A. V. (2019). Effects of thermal radiation using wood stoves on population health: Casas Viejas community, Jipijapa Canton. International Research Journal of Management, IT and Social Sciences, 6(5), 1-8. https://doi.org/10.21744/irjmis.v6n5.656

Wang, L., Zhang, M., Li, Y., Xia, J., \& Ma, R. (2021). Wearable multi-sensor enabled decision support system for environmental comfort evaluation of mutton sheep farming. Computers and Electronics in Agriculture, 187, 106302.https://doi.org/10.1016/j.compag.2021.106302 


\section{Biography of Authors}

\begin{tabular}{|l|l||}
\hline & $\begin{array}{l}\text { I Made Satriya Wibawa } \\
\text { He was born in Baler Bale Agung, 19 May 1966. He graduated bachelor's degree } \\
\text { with Physics Degree in Physics Study Program, Faculty of Mathematics, Gadjah } \\
\text { Mada University (UGM) in 1991, in Instrumentation Physics. He finished a } \\
\text { magister's degree of Physics in Physics Study Program, Faculty of Mathematics, } \\
\text { Institut Teknologi Bandung (ITB) in 1998 in Semiconductor Material Physics. The } \\
\text { research was conducted in the field of Instrumentation, Sensor, and Computation. } \\
\text { Email: satriya_wibawa@unud.ac.id }\end{array}$ \\
\hline
\end{tabular}

Wibawa, I. M. S., \& Putra, I. K. (2022). Design of air temperature and humidity measurement based on Arduino ATmega 328P with DHT22 sensor. International Journal of Physical Sciences and Engineering, 6(1), 9-17. https://doi.org/10.53730/ijpse.v6n1.3065 